\title{
A Study of Living Godess Kumārī: The Source of Cultural Tourism in Nepal
}

\author{
Him Lal Ghimire*
}

\begin{abstract}
The Kumāri- living goddess, as the spirit of the goddess of power believed to be embodied in a long succession of Nepali virgin girls, has been worshiped for centuries. The Kumāri is a prepubescent girl who is hailed as manifestations of divine and spiritual energy, the living incarnation of the Hindu goddess of power; for Buddhist devotees, the Kumāri is a manifestation of Vajradevi or Tara. The most important requirement is that the girl has never menstruated. Hindu and Buddhist devotees bow their forehead on the toes of the living goddesses the Kumāri with high level of respect to fulfil their wishes. The Kumāin is commonly "Mother Deity or Kumārī ma". As a Mother Deity it is believed that the Kumāri can transmit power or śakti directly into the bodies of those devotees who come to have her audience (darśana). The Kumārì culture is Nepali's identity and historical cultural heritage. The Kumārì culture has a huge potential to develop cultural tourism in Nepal however, it has not been well-known to the rest of the world adequately. It is one of the country's oldest tradition and should be preserved.
\end{abstract}

Keywords: manifestations, power, virgin, mandala, darśana, tika, jatra, culture.

\section{Context}

The Kumārī- living goddess, as the spirit of the Talejū goddess believed to be embodied in a long succession of Nepali girls, has been worshiped for centuries. I paid a visit to the Kumārī Ghār (Kumārī House) to collect the field data for this article on May 20, 2017. Hindu and Buddhist devotees bow their forehead on the toes of the living goddesses the Kumārī with high level of respect to fulfil their wishes. I

\footnotetext{
* Dr. Ghimire is a visiting fellow at Nanzan University, Japan; completed Postdoctoral research on Buddhist pilgrimage: Comparison of Shikoku and Lumbini from Nanzan University, Japan; Ph.D. on Pilgrimage Tourism: Special Focus on Lumbini from Tribhuvan Univeristy; MSEd (Leadership for Educational Change) from Bank Street College of Education, New York; a tourism/pilgrimage writer and an educationist; published two books on tourism and 100's of articles on in international and national journals, newspapers and magazine. Email: himghimire@gmail.com
} 
have never got chance to meet her personally and this was my first time in my life to bow my forehead on her toes along with hundreds of other devotees. There were hundreds of foreigners who believe in other religious faith waiting her for a grace from a window.

Nepal, the Himalayan country is situated between China and India steeped in several unique cultures, legends and myths. A beautiful, awe-inspiring land, Nepal is the birthplace of Buddha, the country with the Mount Everest and home to the Kumārī: the living goddesses. Nepal has a unique and diverse living history and culture. It has been blending and carrying the history of thousands of years (Ghimire, 2017). The culture, festivals, traditions, rituals, legends, temples, monasteries, stupas, religious books, archeological remains, structures, caste/ethnic groups and the welcoming nature of Nepalese people are more than enough to prove its authenticity (Kunwar \& Ghimire, 2012). The unique and diverse Nepalese culture has been the attraction for rest of the world. Definitely, the existence of the Kumārī- living goddess in $21^{\text {st }}$ century world would be a curiosity to observe, meet, see, know and read about her for the people around the globe. This article uncovers the history, reality and prospects for tourism development of this culture.

Methodologically, this work is based on both primary and secondary sources such as books, journal articles from the library and the internet; field visits, observation of the authentic evidences and festivals, meet the Kumārī personally, interviews with former Kumārīs, tourists/pilgrims, cultural tourism experts and sacred specialists. An attempt was made to review the books, research papers and articles. The questions to the respondents were basically open ended in nature.

\section{The Kumārī: Divine Identities}

Kumārī is derived from the Sanskrit word Kaumarya, which means princess. The word Kumārī literally means "virgin girl" in Nepali. The Kumārī or Kumārī Devi comes from the Hindu faith however most of the "traditional" Kumārī in Kathmandu are from Newar community. The Kumārī is a prepubescent girl who is hailed as manifestations of divine and spiritual energy, the living incarnation of the Hindu goddess of power Durga who is also named as Talejū (Tulaja) Bhawani, Bhagawati, Kālī, Pārvatī, Tripurasundarī, Ambikā etc. As a slayer of invincible enemies, Durgā is identified not just as $a$ goddess, but as the goddess, called Mahā Devī or "great goddess". Consequently, she is understood to be the source of and to contain all other goddesses within her. For this reason, the Kumārī, Durgā’s living incarnation (avatāra) on earth, can and is addressed by the names of other popular Hindu goddesses (Lidke, 2010); for Buddhist devotees, the Kumārī is a manifestation of Vajradevi or Tara. These Kumārīs are strictly connected with Newar Buddhist monasteries (baha) and specific caste groups and localities, and special associations ( $g u t h i)$ are formed for their cult. 
They live a sheltered life until they reach puberty, and are worshipped in Nepal by both Hindus and Buddhists. Worshipping virgin girls as the goddess Kumārī is a very old Hindu practice, which has also long been symbolically central to the culture of the Newars of the Kathmandu Valley. Numerous Kumārīs living in the different neighborhoods of Newar cities and in surrounding villages are worshipped (Slusser, 1982; Allen, 1996; Shrestha, 2002; in Letizia, 2013, p. 35). Interestingly, the Kumārī is always chosen from the Shakya clan. Though the Kumārī is Buddhist by birth, the Talejū is a very important Hindu Goddess. This unique tradition is a perfect example of the intertwining and religious harmony in Nepal that has long been known for.

The Kumārī as a goddess of the nation used to bless the king by marking his forehead with red vermilion paste ( $t i k a$ ), thus legitimating his rule for one more year. There are actually eleven living goddesses in Nepal known as the Kumārī. They are chosen for various towns because Kumārīs are believed to protect the towns from evil powers. The three most important Kumārīs are each associated with one of the three main towns of the Kathmandu Valley: Patan, Bhaktapur and Kathmandu. The Kumārī of Kathmandu (the Royal Kumārī in the past) is by far the most influential and revered (Bhattarai \& Shrestha, 2010). The cult of Kumārī has been central to legitimating Hindu kings (then and there): different mythological accounts relate the origin of Kumārī as a form taken by Taleju. The legend behind establishing the Kumārī tradition is King Jayaprakash Mall used to go the Goddess Taleju place in the night in order to play dice with her. After some time, the queen was worried about king's regular disappearing during night. One night she followed him and saw him along with Taleju. Then goddess got angered and disappeared immediately. This incident made the king restless. One-day goddess Taleju came to his dream and told to the king that she would not return anymore. Rather, she asked the king if he would want to protect his country, he has to establish a Kumārī Ghar and find a virgin girl from Shakay clan of Newar. Taleju would incarnate in her. Since, then, Jayaprakash Malla started this system of worshiping virgin girl as a living deity. During the Malla period (fourteenth to eighteenth century), the three kingdoms of Kathmandu, Lalitpur, and Bhaktapur each had its own royal Kumārī, near the king's palace. With the unification of Nepal, the Kumārī of Kathmandu became the sole royal - and now national - Kumārī. What follows concerns mainly this national Kumārī, whose ritual life is more strictly regulated, although many of the rules apply, with some variations, to the Kumārīs of Lalitpur and Bhaktapur (Letizia, 2013, p.36). Kumārīs are believed to have powers of prescience and the ability to cure the sick (particularly those suffering from blood disorders), fulfill specific wishes, and bestow blessings of protection and prosperity. They are also said to provide an immediate connection between this world and the divine and to generate in their devotees maitri bhavana-a spirit of loving-kindness toward all (Tree, 2015). Lidke (2010) writes the identification of the Kumārī with the 
Great Goddess, Mahā Devī, reveals a key facet of her identity and function as a living divinity: she is the embodiment of a power (śakti) that protects the nation against any and all enemies of state. To understand how a small virgin girl can embody such awesome power, one must take into account the ritual ideology and practice that under girds the Kumārī institution. It is ritual that transforms the young virginal girl into a divinity capable of destroying all enemies.

The transforming virgin girls into divine Kumārīs stem from Tantra, a system of ritual practice and related ideologies that date back to the $4^{\text {th }}$ century. The Tantric tradition-which cuts across the divide between 'Hindu' and 'Buddhist' - assumes that all of existence is an unfolding of a singular conscious energy or śakti that manifests itself according to a precise geometrical and acoustic pattern termed mandala (territory). They believe that the universe itself is the grandest of mandalas, being the cosmic emanation of śakti. Girls designated to serve as the Kumārīs are selected because their young, virginal bodies are deemed qualified to serve the nation as vessels for this harnessing of divine power. Through ritual they are temporarily transformed into that cosmic power that is depicted mythologically as Durgā/Talejūand iconographically as that mandala structure whose perfect interwoven forms are the powerpatterns that protect the region-at the cosmic, bodily, and state levels-from all enemies. (Lidke, 2010).

The transforming process of virgin Nepalese girls into living conduits of these real unseen powers are described in sacred ritual texts called Paddhatis. Paddhatis detail ritual prescriptions for daily worship, festival worship, and worship for specific intentions, such as the power to win an election, get public support etc. Of these three types of ritual the most common and most important is the daily ritual. Once the Kumārī is chosen, she must be ritually purified each day so that she can be an unblemished vessel for Taleju. The heart of the ritual is the placement of the Kumāri on a ritual seat shaped in the form of a mandala while a Tantric priests (both Hindus and Buddhists) worships her with special body postures (mudrās) and liturgical formulae (mantras) that empower her body to be a living manifestation of what the Paddhatis call the Goddess of Universal Form (viśvarūpa-devī). By the completion of each daily ritual, it understood that the power of the supreme goddess (parādevī) fully resides in the human form of the Royal Kumāri and that therefore she deserves the official title of Taleju, identifying her as the king's own sovereign deity (Lidke, 2010).

\section{Kumārī Jatra: A Sensational Gathering in Kathmandu}

The Kumārī Jatra festival is played out annually in September. Kumārī Jatra is the part of the celebration of Indra Jatra, which is the largest public festival in Kathmandu. The Indra Jatra festival is one of the most exciting and revered festivals 
of the Newar community in the Kathmandu Valley. It begins with the erection of a wooden pole made of pine at Basantapur Durbar Sqaure in front of the old Hanuman Dhoka Palace. On this occasion, the living goddess in all her bejewelled splendor is borne in a palanquin in a religious procession, huge crowd of devotees gather to witness the procession of the Kumārī in her enormous chariot and seek her blessings. The chariot, set on massive wheels, covered with gold plated copper sheeting, and culminating in a double roofed pagoda, travels the main thoroughfares of Kathmandu on a scheduled route for three days. The chariot of the Kumāri followed by two other smaller chariots carrying a representative of Ganesh and Bhairav is taken to different parts of the old Kathmandu. There is a story behind to celebrate Indra Jatra Festival in Kathmandu. Once Indra's mother needed parijat (night-flowering coral jasmine, or simply fragrance), a type of flower, for some religious ritual. Indra disguised as a human being came to the earth to fetch them. But, he was recognized when he was to steal the flowers. The local people caught him and tied him with ropes and wanted to humiliate him publically for his guilty. The statue of which is still worshipped in Maru Tole in Kathmandu. This incident happened during the Kumārī Jatra. This image is also put on display with others in different parts of the city during Indra Jatra festival.

The participation of the head of state started with the Malla King Jaya Prakash Malla, and ended with the last king Gyanendra Bir Bikram Shaha. The participation of head of state (then and there king and currently the president) amid huge crowds in the streets of Kathmandu and an assembly of state dignitaries and ambassadors substantiates the long-lasting relation between the living goddess Kumārī and the head of state. Nepal has become the republic country; the king has now replaced by the president. During this festival the Kumārī blesses the president (King in the past), in keeping with the tradition in which Prithivi Narayan Shah received a blessing from the living goddess. The Goddess Kumārì is regarded as so powerful that this annual blessing of the president (King and the royal family in the past), and government officials and state dignitaries is considered essential to the successful reign of all sovereigns.

Indra Jatra is celebrated for eight days. Masked dancers known as Lakhay take to the streets almost every evening accompanied by loud drums. The shrines and ancient palace buildings around Basantapur Durbar Square are aglow with oil wicks, there is an enactment depicting the ten earthly incarnations of Lord Vishnu on the platform in front of the temple of the Living Goddess each night of Indra Jatra. The festival of Indra Jatra ends with the lowering of the (lingam) pole bearing Indra's flag amidst religious ceremonies. On the last day of the Kumārī Jatra, the the president (king in the past) traditionally presented himself/herself before the Kumāri to receive a red mark called tika on his/her forehead, an annual ritual legitimating his/her right 
to rule. This tradition, probably started by King Jaya Prakash Malla in the eighteenth century, was appropriated by the subsequent dynasty and finally continued with the presidential system. The Kumārī continues performing her legitimating ritual for every head of state, as she has done since at least the eighteenth century.

\section{Selection of the Kumāri}

Once the current Kumārī, the Kumārī in Basantapur who is considered as national Kumārī or royal Kumārī in the past is no longer eligible to be a vessel for the goddess the search begins to find an appropriate successor. The Kumārī is always chosen from the pure Shakya clan for at least three generations of Kathmandu's Newar community (Shakya, 2017). Normally it is a privilege to have your daughter contest in this selection process. Young girls must have the 32 lachchins (perfections) of the goddess in order to be the Kumārī. The list of requirements is elaborate:

- Must have perfect health without any history of serious illness

- Unblemished skin

- Black straight hair curled towards the right side

- Gorgeous expressive/Dark eyes

- Sonorous crystal clear voice

- Long slender arms

- Delicate and soft hands and feet

- No bad body smells

- Must not have shed any blood

- Virgin with an unblemished body

- Body of the Banyan tree

- Eyebrows like the cow

- White teeth without any gaps

- Mona Lisa like smile

- Thighs like those of a deer

- Neck like a conch-shell

- Tongue - small and moist

- Twenty unbroken teeth should be present

- Sexual organs small and well-recessed

The most important requirement is that the girl has never menstruated. The is a belief that when a Kumārī has her first menstruation, she loses her divine power 
and is returned back to life as an ordinary girl. If the girl starts menstruating while serving as Kumārī, it is considered inauspicious. She must have a sense of courage and should not fear a masked man or an animal sacrifice and she must never have lost a drop of blood. Her family's reputation for piety is taken into consideration by the selection committee, which also looks for calmness and fearlessness in the girl. To ensure the girl's compatibility with the King of Nepal, her horoscope was to be compared and must match with his, as the Kumārī has an important role in relation to the King, including the traditional power to confirm the King's rule in the past (Bhattarai \& Shrestha, 2010). Now time and situation has been changed because of this, some ritual aspects have necessarily changed, as the connection that linked the Kumārī and the king has been severed. The Kumārī selecting committee no longer verifies whether the Kumārīss horoscope matches the president's or former king's, and the royal priest (rajpurohita) is no longer involved in selecting a new Kumārī.

During the eighth day of Dashain, called Kalratri (black night), selection process of the Kumārī begins. The Kumārī (3-year girl) is left in a room with 108 decapitated buffalos and goats laid out in a sea of blood with men wearing horrid masks dancing among them to test the fearlessness of the girl. If the child gets scared and cries, she will be disqualified and the next girl has to go though the process until they find a girl who can smile in that surrounding and enjoy the dance of the masks men. The young girl is taken into the Talej $\bar{u}$ temple's courtyard where the severed heads of the animals are illuminated by candles and masked men dance about. The child must show no fear during any of this. Finally, the girl must spend a night with slaughtered heads of the animals and again show no fear. If she passes these tests the girl is taken for ritual cleansing of her past life. Adorned with the Kumārì clothes and taken to her new house (the Kumārī House). The above are the strict and official rules for national Kumārī in Bashantapur. However, many of the Kumārīs in Lalitpur, Bhaktapur and other cities do get to see their families and indeed some of the the family members live with them.

\section{Daily life of the Kumārī}

There are only fifteen days in a year when the Kumārī comes out from her temple for festivals. Separated from her parents, she lives in the "Kumārī House" near the ancient palace of the Malla kings in Basantapur, Kathmandu. She receives care, instruction and other necessary services from the assistants. Newars and all Nepalese, Buddhists and Hindus alike, come to worship her regularly in her house, and on the occasion of religious celebrations, when she travels outside her palace on a chariot.

Per tradition, active Kumārī are considered to be omniscient, and thus receive no education as children. Once she becomes mortal, however, ex-Kumārī are allowed to reintegrate into the modern education system, and attend school. However, the 
time, situation, constitution, head of state etc. have been changed. With the direction from King Birendra Bikram Shah, the formal education of the Kumārī started in 1978 (Shakya, 2017). The present Kumārī who had joined a preschool before becoming the Kumārī receives regular classes of different subjects from the teachers (mostly form the same school) and her caregivers. After retirement (11 years) from the Kumārī, she can join regular school.

Table 1: The usual schedule of the Kumārī

\begin{tabular}{|l|l|}
\hline \multicolumn{1}{|c|}{ Activities } & \multicolumn{1}{c|}{ Time } \\
\hline Weak up & Mostly by 7.00 a.m. \\
\hline Cleaning, bathing etc. & $7.00-8.00$ a.m. \\
\hline Breakfast & 8.00 a.m. \\
\hline Nitya (Regular) Puja by Hindu and Buddhist priest & 8.30 a.m. \\
\hline $\begin{array}{l}\text { Worshiping by (Hindu and Buddhist) devotees and public } \\
\text { grace to the non-Hindu and Buddhist visitors from the } \\
\text { window }\end{array}$ & 9.00 a.m.-12.00 noon \\
\hline Lunch & 12.00 noon \\
\hline Study hours with teachers & 1.00 p.m.- 4.00 p.m. \\
\hline $\begin{array}{l}\text { Worshiping by (Hindu and Buddhist) devotees and public } \\
\text { grace to the non-Hindu and Buddhist visitors from the } \\
\text { window }\end{array}$ & 4.00 p.m.- 6.00 p.m. \\
\hline Leisure time/Homework/assignment & 6.00 p.m.-7.00 p.m. \\
\hline Dinner & 7.00 p.m \\
\hline Study hour (Homework/assignment) & 7.30 p.m.-8.30 p.m. \\
\hline Bed time & 8.30 p.m \\
\hline
\end{tabular}

Many politicians, former royal members, government officers, businessman and general public visit the Kumārī seeking a blessing for their duties on a regular basis. The Kumārī gives a read mark (tika) to the visitors but she never talks with them. Many women (specially girls) visit the Kumārī with blood or menstruation problems due to her association with the subject. It is believed that a look from the Kumārī will tell one's future wealth, health and status.

These include:

- Picking at food offerings will be associated with financial losses

- Crying is associated with illness or death

- Trembling means an impending imprisonment 
- Silence is perhaps the greatest thing for a visitor as it means their wishes are likely to be upheld

The Kumārī is commonly "Mother Deity or Kumārī ma”. As a Mother Deity it is believed that the Kumārī can transmit power or śakti directly into the bodies of those devotees who come to have her audience (darśana). For this reason, every day, after the daily ritual, the Kumārī receives the faithful in her inner chambers for a brief period, providing an opportunity for direct contact with living divinity. In other words, the ritual is the medium of transformation. Through ritual a human girl becomes the microcosmic embodiment of the goddess (Lidke, 2010). The Kumārī is not allowed to walk, touch or talk to anyone outside her family, in order to preserve her purity. For the youngest Kumārīs, this means they will not learn to walk until they are retired as teenagers. Every day, the Kumārīs care takers/mother dresses her in red clothing, applies dark makeup around her eyes and lips, and paints special designs on her forehead.

\section{Chronology of the Kumārī}

Both the Hindu and Nepali histories of the Kumārī are vast and intricate. There is evidence of virgin worship in Nepal dating back to the 6th century. However, the Kumāri only became evident in the 17th century in Nepal. There are several legends that tell of how the Kumārī came to be in Nepal. Today there are many Kumārī in Nepal. Indeed, unknown to many, most Newari villages have a "Kumārī". However, the Kumārī in Basantapur Durbar Square in Kathmandu is the most senior and well known.

Table 2: Chronology of the National Kumārī (Kathmandu)

\begin{tabular}{|l|l|l|}
\hline \multicolumn{1}{|c|}{ Name of the Kumārī } & \multicolumn{1}{|c|}{ Duration } & \multicolumn{1}{c|}{ Family status } \\
\hline Hira Maiya Shakya & $1922-1923 \quad(1979-1980 \mathrm{BS})$ & Married \\
\hline Chini Shova Shakya $^{\star}$ & $1923-1931 \quad(1980-1988 \mathrm{BS})$ & Married/ 2 daughters \\
\hline Chandra Devi Shakya $^{\star}$ & $1931-1933(1988-1990 \mathrm{BS})$ & Married/ 2 daughters \\
\hline Dil Kumārī Shakya & $1933-1942(1990-1999 \mathrm{BS})$ & $\begin{array}{l}\text { Married/ 3 sons, } \\
\text { daughter }\end{array}$ \\
\hline Nani Shova Shakya & $1942-1949(1999-2006 \mathrm{BS})$ & $\begin{array}{l}\text { Married/ 4 sons, } 2 \\
\text { daughters }\end{array}$ \\
\hline Kyo Mayju Shakya* & $1949-1955 \quad(2006-2012 \mathrm{BS})$ & $\begin{array}{l}\text { Married/ 1 son, 1 } \\
\text { daughter }\end{array}$ \\
\hline Harsha Laxmi Shakya & $1955-1961 \quad(2012-2018 \mathrm{BS})$ & Married/ 2 sons \\
\hline
\end{tabular}




\begin{tabular}{|l|l|l|}
\hline \multicolumn{1}{|c|}{ Name of the Kumārī } & \multicolumn{1}{|c|}{ Duration } & \multicolumn{1}{|c|}{ Family status } \\
\hline Nani Mayju Shakya & $1961-1969(2018-2026 \mathrm{BS})$ & $\begin{array}{l}\text { Married/ 1 son, 2 } \\
\text { daughters }\end{array}$ \\
\hline Sunita Shakya & $1969-1978 \quad(2026-2035 \mathrm{BS})$ & $\begin{array}{l}\text { Married/ 1 son, 1 } \\
\text { daughter }\end{array}$ \\
\hline Anita Shakya & $1978-1984(2035-2041 \mathrm{BS})$ & Married/ \\
\hline Rasmila Shakya & $1984-1991(2041-2048 \mathrm{BS})$ & Married/ \\
\hline Amita Shakya & $1991-2001 \quad(2048-2058 \mathrm{BS})$ & Unmarried \\
\hline Priti Shakya & $2001-2008(2058-2065 \mathrm{BS})$ & Unmarried \\
\hline Matina Shakya & $2008-2017(2065-2074 \mathrm{BS})$ & Recently retired \\
\hline New Kumārī & 2017- to date (2074-todate) & $\begin{array}{l}\text { Recently appointed } \\
\text { (Sept. 8, 2017) }\end{array}$ \\
\hline
\end{tabular}

Source: Shakya, 2010, Field visit, 2017 ( ${ }^{\star}$ Died)

Four years old new Kumārī has been recently appointed. She was a Pre-school student before she became new Kumārī. The Kumārī management do not disclose new Kumārì's name until she retires.

\section{Dress, Ornaments and Decoration}

The Kumāri is considered the perfect gorgeousness of Nepal and especially in the Newar community, a girl's beauty is often compared to that of the Kumārí. The clothing, ornaments and decoration of the Kumārī has been always fascinated westerners and even Nepalese. Not only during festivals and other formal occasions, the Kumāri is always dressed in red, because red is considered the color of gods and power among Hindus in Nepal. The Kumārī wears a bright red jama (cloak) down to her feet, a red chaubandi cholo (shirt), and a red pagari (turban) of a pure and special fabrics. She wears ornaments not only around her neck but also on her hands and feet; her hair is gathered in a topknot and decorated with sweet smelling flowers. She bears a third eye (called 'tri-netra') painted on her forehead. The third eye is considered as a metaphorical eye, which is believed to destroy all the evil in the world. The Kumārīs red tika, which is placed on her forehead (above the third eye) artistically during festivals, is called bhrigu. It represents the cosmic energy of the earth. This brightest and most glowing tika is a sign of wealth, prosperity and a bright future for the nation. The special tika is prepared by mixing vermilion powder, rock crystal powder, a kind of sweet scented natural powder called 'kumkum' and sesame seed oil. 
The Kumārī wears garlands of diamonds and gold coins, and two necklaces of special symbolic significance. One is a golden chain made in the shape of the serpent god called 'Basuki Naga' on her neck, hanging down to her belly. This ornament has multiple meanings. Firstly, it is considered a symbol of the guardian of the national treasury because Basuki Naga was reincarnated as lord Kuber (guardian god of wealth). The Kumārī is also worshiped as the goddess of wealth, Lāxmi, during the Tihar festival. Secondly, the serpent is often used as a symbol of anger. Thirdly, the serpent god Naga is also closely related to the monsoon, the most important of all seasons for farmers, as during this time snakes frequently bite farmers. Therefore, people also worship Naga during Kumārī Pujā for protection: of their wealth, and from anger and snake bite.

Another ornament the living goddess wears is a four-inch-long golden tā-yo:, which, has a cylindrical body with a number of edges and a conical shape at both ends. This is sheltered under the umbrella of an eight-headed miniature golden Naga, which symbolizes the eight mother goddesses. The Kumārī wears it around her neck (it extends down to her chest) to indicate her authority with the eight mother goddesses. She also wares beruwa aunthi (gold rings) on fingers, bala (bracelets) and chura on arms. It is believed that these ornaments were prepared near the end of the rule of the Malla kings, when the Kumārī tradition began. The ceremonial clothes and ornaments are passed from one Kumārī to the next, through the ages. On nonfestival days (regular days) the Kumārī wears ordinary clothes, which are the offerings of people who come to worship her.

\section{Life after the goddess leaves a Kumārī}

A grand farewell programme is organized for an outgoing Kumārī when a new Kumārī takes her position. The Kumārī girl has to spend twelve days in a room purifying herself and getting ready to transition back to regular life. A living goddess of Nepal a day before becomes a normal girl in the next day. Then, she is immediately regarded as a normal child and given back to her parents. A small token pension is awarded to her. Manita Shakya who was retied on September 8, 2017 recently joined elementary school in October 2017. Yun (2011) gives a title Cyber Kumārī to Rashmila Shakya, one of the ex-Kumārī. Rashmila thoroughly enjoyed her reign as the living goddess, but now has more mundane things to attend to as she designs banking software in an IT firm in Kathmandu. She is probably one of the best known ex-Kumārīs of all time. This is mainly due to the success of her autographical book, From Goddess to Mortal, co-authored with Scott Berry in 2005. Rashmila is the first ex- Kumārī with a bachelor's degree despite being nearly illiterate when she stepped down as Kumārī at age 12. "It was difficult," she confides, "and even after graduation it has been difficult to find a job." After working for a support group which shelters the urban poor, Lumanti, she is now working on banking software in a computer company. 
Yun further writes Anita Shakya, on the other hand, is a more traditional ex- Kumārī, hardly venturing outside the house. Slightly shy, she says she enjoys cooking and doing household chores for her tightly knit extended family. She has passed Grade ten and watches Television, dramas during her spare time, and is supported by her loving relatives. Chanira Bajracharya, a former Kumārī says, "Being a goddess is just like being a princess and you get everything at home. I never missed going outside, but rather enjoyed staying at home and being part of the divine life. When I had to step out of my house for the first time, I didn't know how to walk properly. My mom and dad, they used to hold my hands and teach me how to walk."

\section{The Kumārī Ghār (House)}

Majestic Basantapur Darbar Square is a former royal compound and a contemplative's haven with mystical temples and the 'living goddess' Kumārī right there with her family in a simple palace. Overlooking the south side of Basantapur Durbar Square, the Kumārī Ghār (House of the living goddess) is a three-story brick building richly decorated with wood-carved reliefs of gods and symbols. It was built in 1757 by King Jaya Prakash Malla and renovated in 1966. A narrow wooden staircase leads up to the second floor, where the goddess spends much of her childhood. Tourists can enter the courtyard, where there are more beautiful reliefs over the doors, on the pillars and around the windows. Photos are permitted in the courtyard, but it is strictly forbidden to photograph the Kumārī. The Living Goddess sometimes appears in one of the second-floor windows, especially if her handlers are paid well enough, and is said to answer devotees' questions with the expressions on her face. She is most likely to appear in the morning or late afternoon.

\section{Authenticity and Tourism}

Authenticity refers to original, genuineness or true to reality. As per Theobald (1998), authenticity means genuine, unadulterated or the real thing. In tourism, authenticity refers to experience a different way of life, manifestation of the identity of a people, customs, traditions, heritage, history and identity. The discovery of places in a country that remain untouched by modernism and still maintain traditional methods and ways of life and travel with added value and quality of experience signify the authenticity (Kunwar \& Ghimire, 2012). Far from being content with inauthentic existence, MacCannell's tourists are on a modern day "quest" in search of authenticity. These tourists constantly attempt to go behind the "staged authenticity" of the surface in order to reach the "reality" that presumably lies there (MacCannell, 1976). There have been many reasons to travel to seek fortune in faraway lands, to seek religious experience in a pilgrimage, to seek the personal and national aggrandizement of colonial conquest, or to seek escape, in exile, from persecution. Stories of those who sought escape from the everyday reality of home are the stuff of great mythology. By 
stepping out of the reality of the familiar and the everyday life, these travellers have provided rich symbols of heroic confrontation with the unknown and the mysterious. While the actual experiences of these earlier travellers may have been less than heroic, they have been viewed metaphorically in heroic terms good, evil, or tragic (Redfoot, 1984; in Kunwar \& Ghimire, 2012).

In perceived authenticity, the tourists before their departure are subject to have an idea about the images of the destination. The original authenticity is represented by the natural and man-made features which attract visitors to the destination (Jackson, 1989; in Kunwar, 2002:118). The writings, videos and promotional materials can give general idea about the site before they visit. Wang (1999) gave a taxonomy of three types of authenticity in tourist experiences. Before the examination of the interaction between object-related and existential authenticity, the nature of object-related authenticity needs to be further clarified. It was also taken from the constructivist perspective. The five characteristics that Wang identified as common to constructivist approaches outlined the general assumptions and orientations of that school of thought, but do not address the specific meaningful elements used to construct notions of authenticity. The present task, then, is to answer the question "What makes an object of the tourist gaze seem authentic to the viewer?" The answer rests in idealized conceptions located within impermeable boundaries, communicated symbolically and legitimated by authority. Assuming that there cannot be objective authenticity, why do people 'believe' in its existence? Constructivist philosophers assume that there is no real pre-existing world independent of human activity. Nothing is inherently authentic; authenticity is constructed by a society based on points of view, beliefs, perspectives, interpretations or powers. Therefore, what consumers or tourists do is projecting their expectations, preferences, consciousness and stereotyped images onto toured objects and sites and believe them to be authentic when they meet their expectations. For constructivists, authenticity is elative, negotiable, contextually determined and even ideological. Wang provides an important differentiation between the completing definitions of authenticity within the context of pilgrimage and heritage tourism. Authenticity in tourism can be applied to both the visitor experience (activityrelated authenticity) and the toured objects themselves (object-related authenticity). Wang's existential definition of authenticity deals with the activities or experience of the visitor, both objective and constructive definitions of authenticity focus more on objects, or the heritage tourism product that has been developed. Because the goal of this study is to better understand the role of authenticity in the pilgrimage tourism development process (creating objects or products for consumption), Wang's objective and constructive definitions of object-related authenticity are used as the basis for exploring stakeholder beliefs and opinions (Kunwar \& Ghimire, 2012). 
Figure 1: Wang's Taxonomy of Three Types of Authenticity in Tourist Experiences

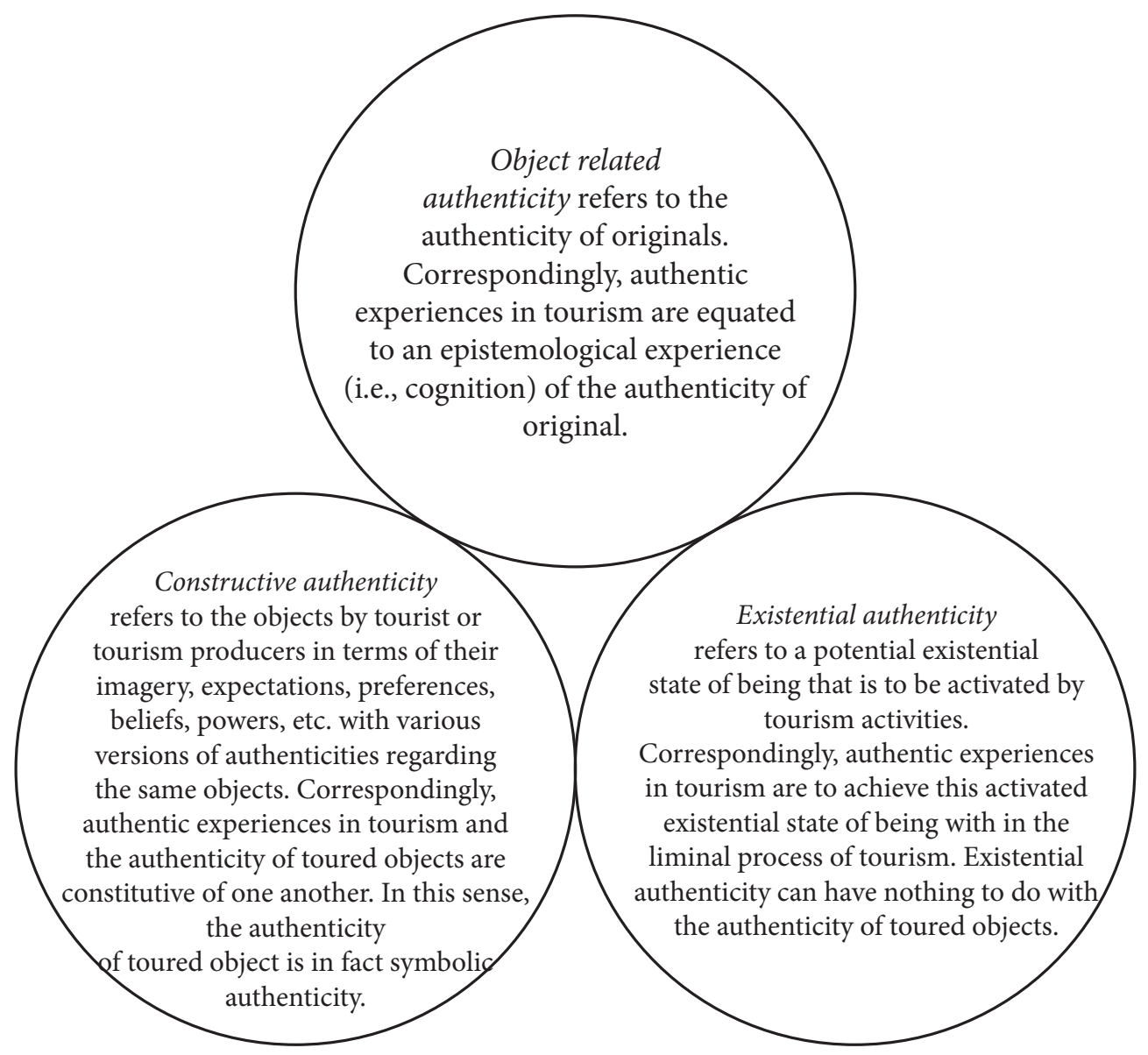

Source: Wang, 1999, p. 352

"Authenticity" is one of the core concepts in tourism. It gives theoretical explanation of tourism attractions from the angle of tourist motivation and tourists' perception. The search for authenticity reflects the needs of urban tourists from industrial countries. When they travel, they seek to experience something new outside their daily lives, something innovative and different. They want to experience new things and enjoy the sensation of being where things are real and original. They want to share the joyful moment with other people or write a note "I was there". MacCannell's tourist, however, is concerned with the authenticity of attraction. The quest for authenticity, indeed, rather than the search for contrived illusions, is said to be the fundamental 
motivation of modern tourists. Modern tourists, however, alienated from their own inauthentic and shallow world, may seek authenticity elsewhere in other times and places (MacCannell, 1976, p. 3; in Kunwar \& Ghimire, 2012).

Authenticity can be measured in terms of the tourist's own values and satisfactions. It occurs when travellers return home feeling they have truly experienced a change in scenery, gained a better understanding of the country visited and its development, or connected in some way with the local population. Tourists seek for authentic destination, culture, practices, events, food etc. The Kumārī culture-living goddess in Nepal could be one of the most important authentic and unique experiences for both domestic and international tourists.

\section{Prospects of Kumārī Tradition: Touristic Attraction}

Deities are strictly relegated to the spiritual realm, never actually seen by mortal devotees on Earth. Nepal is the only country where one can meet and receive blessings from the Kumārī - living goddesses who is believed to be the human incarnation of Durgā, the demon-slaying Hindu goddess of power. The Kumārì’s status in Nepalese society mostly be higher than even the president's (king in the past) while virgin worship has existed in Nepal for millennia, this particular form started around the 17th century. Allen (2011) particularizes about the diagnostic feature of the Kumāri worship. The idea that a young virgin girl can, through the performance of complex ritual, become a powerful goddess, is simply but one, albeit a dramatic and in many ways beautiful, example of what is in fact a key feature of Hinduism and Buddhism, the idea that divinity is in fact immanent everywhere in the phenomenal universe. Most visitors to Kathmandu valley are immediately impressed by the immense proliferation of physical manifestations of the sacred or divine. As well as the countless temples and shrines dedicated to almost every known deity of both Hindu and Buddhist pantheons, not to mention numerous others of purely local significance, there is an almost infinite number of sacred places and objects scattered thought the valley: some manmade structures, such as chāityās, stupas, lingās, wells, statues and cremation grounds, other natural features, such as trees, stones, caves, rivers, hilltops and above all else, humans. Tourists (non Hindu and Buddhist) flock to get a glimpse of the Kumārī atop her heavily decorated throne, and locals (both Hindus and Buddhists) regularly present her with fruit, flowers and money, hoping she will bestow good luck and prosperity upon them. Being chosen for the position is regarded as the highest honor, one that can bestow innumerable blessings on a Kumārīs family. So despite the financial burden and personal sacrifices involved in maintaining a young girl as a living goddess in the modern world, and the challenges of her rehabilitation once she reaches puberty and has to live a normal life again, certain families are still prepared to put their daughters forward for selection (Tree, 2015). Life as a living goddess was viewed as a route to a better life in the past. 
The Kumārī did not lose her status under the new republic, and her legitimating function appears to have remained unquestioned. In 2007, Girija Prasad Koirala, who was temporarily serving both as prime minister and head of state of Nepal, took the exking Gyanendra Shah's place, after the latter had been stripped of his "cultural rights". Nevertheless, the king also went to take the tika, underscoring with this gesture the importance of the Kumārī as a symbol of legitimization. In 2008 a new Kumārī, the three- year-old Matina Shakya, was selected, and the first elected president Ram Baran Yadav went to the Kumārī House to receive the Kumārìs blessings. Since 2009, she has regularly blessed the president during the Kumārī Jatra festival (Letizia, 2013, 36). The Kumārīs' identity is by no means shaped solely by traditional Hindu theology and myth. The central power of the Kumārī institution is that it functions as a ritual mirror in which Nepal's multiple ethnic groups see reflected their respective cultural values (Lidke, 2010). The Kumārī culture has been the institution and Nepal is the land of living goddess which could be the pillar of tourism development in Nepal (Kunwar, 2017). The Kumārī culture had been age long, authentic and unique culture in Nepal. The locals who have been part of this tradition will continue it whether they get support from the government or not, however, the government has main role to preserve this tradition (Shrestha, 2017). Definitely, existence of the Kumārī- Living goddess would be an exceptional and unique culture for rest of the world. Hindus and Buddhists people can meet personally, worship and get blessings from her. The Kumārī goddess is one such custom that is fascinating to the foreign eye. That is why; the Kumāri-living goddess is the main attractions for tourists visiting in Nepal. I had made several visits at the Kumārī house, Bashantapur, Kasthmandu. The field visits, interaction with locals, talks with tourists shows that more than sixty percentage of international tourists visiting in Nepal and go for a sightseeing in the Kathmandu valley visit to the Kumārī house. A large number of tourists with other religious faiths visit Kumārī Ghar and wait in the court yard of the Kumārī house for her grace from a window in the second floor patiently as they are not allowing to go upstairs of the Kumārī house and meet her personally. The domestic Hindu and Buddhist devotees visit to the Kumārī house for worshiping the Kumārī throughout the year. However, we can see a crowd on Saturdays, Tuesdays and festival days. The Kumārì culture has a huge potential to develop cultural tourism in Nepal, however, it has not been well-known to the target tourists group adequately. The Kumārī culture is Nepali's identity and historical cultural heritage. The government should not abolish this even though political scenario is changed rather preserve for peace, harmony and well-being of the nation.

\section{Challenges of Kumārī Tradition}

The beginning of the $21^{\text {st }}$ century has been a complex and profoundly interesting time in the history of the Kumārī. Nepalese kingship - the institution that established the Kumāri tradition-has become a monument of the past. From the perspective 
of the faithful, the Kūmārī is the supreme goddess, called by many names (Lidke, 2015). Nepal now has a constitution that guarantees equal rights to women, and more women are getting educated and competing for jobs once held exclusively by men. In recent years the tradition has come under criticism from human rights activists who say it is a form of child abuse that hinders the girls' freedom and education and is especially detrimental to the royal Kathmandu and Patan Kumārīs, who must observe strict rules of purity and segregation (Tree, 2015). Ten-year-old Sajani Shakya, the Kumārì of Bhaktapur after visiting the US to attend the release of a documentary about the Kumārī, was removed from her position by an elder council in 2007. This was for breaking the Kumārī tradition of letting her feet touch the ground and leaving her residence. There is a belief that foreign travel makes one impure, some Hindu and Buddhist priests in Bhatkapur have declared that Sajani can no longer hold the office of living goddess. After much debate she was reinstated after a re-cleansing ceremony.

The Kumārī candidate must endure difficult tests, including spending a night among the heads of ritually slaughtered goats and buffaloes during selection process. A living goddess must come from a specific Buddhist clan the Shakyas. She can have only a few selected playmates. She sees the outside world a few times a year when she is wheeled through the capital on a chariot pulled by devotees. The goddess must always wear red, tie her hair in a topknot and have a third eye painted on her forehead.

Tree (2015) had a talk with Chanira-the ex-Kumārī. "Being Kumārī is a gift. I feel blessed that I was chosen," Chanira added. "But there are things that should be improved for the welfare of the Kumārīs. Like greater financial support from the government to cover the expenses of rituals and the goddess's education. And counseling to explain how her life will change after she finishes as Kumārī. I would like to see a support network of former Kumārīs helping those who have just been dismissed. I am worried that if we do not see these changes, we may lose the tradition altogether."

At present, the system of Kumārī has become more liberal that, the Kumārī is provided with a private teacher for her studies, she can use modern technologies like computers, internet, email and social sites, she is provided nutritious food with sanitation and so forth. Her family members can meet her at any time and can spend as much time as per their wish. Many people view the life of Kumārī is just as life in hostel. Ranabhat (2016) writes activists argued that the social discrimination and cultural victimization are appearing, the supreme court could not make verdict on abolishing the Kumārī tradition, to the respect of cultural aspect, suggest for incorporating the child right, that is appropriate to her. This case became cultural more than right of a person. 
The old Kumārī house is damaged by the devastating earthquakes in 2015. However, the Kumārì and her care takers reside in the building. The visitors and worshipers regularly visit her. Now, the building has been protected with the wooden pillars. There is a challenge how to protect and preserve the old building and provide safe environment for the nation's living goddess. Kunwar (2017) stress the need of cultural heritage awareness among stakeholders of the Kumārī culture. There is need of cultural heritage education programmes in both community (local) and academic institutions.

\section{Conclusion}

Despite the defects, criticisms and outdated superstitions, the Kumārì culture preserves a sacrosanct tradition that has been handed down through generations. The Kumārì has been the powerful goddess connected to the protection of the country. Nepal should learn how to make its culture rich and safe instead of abolishing it, because it is centuries long tradition and this need to be kept alive for the future generation so they can learn and know more about it. Many of the foreign countries are spending millions to preserve their history and culture, Nepal should follow it. Otherwise, it will be sad to see this tradition stopped. The cultural identity is more important than political identity as it is Nepal's unique culture, tradition and prestige. It is one of the country's oldest authentic tradition and should be preserved. It also brings financial gain by attracting larger number of national and international tourists.

\section{References}

Anderson, M.M. (1971). The Festivals of Nepal. London: Allen and Unwin.

Allen, M. (2011). The Worship of Young Virgin Girls as Goddesses in the Secular State of Nepal. (unpublished seminar paper). University of Sydney (Retrieved from: https://www.academia.edu/29746418/Kumārī_and_the_Maoists_in_Nepal_ unpublished_seminar_paper_).

Bhattarai, P. \& Shrestha, B. (2010) Kumārī: A Tradition of Power, Pageantry and Beauty. ECS Nepal (Retrieved from: http://ecs.com.np/features/Kumārī-atradition-of-power-pageantry-and-beauty).

Ghimire, H. L. (2017) Buddhist Pilgrimage A Comparison of Lumbini and Shikoku. Bulletin. Nagoya: Nanzan Institute for Religion \& Culture, 41: 21-55.

Kunwar, R. R. \& Ghimire, H. L. (2012) Lumbini as International Pilgrimage Destination: Authenticity and Significance. THE GAZE Journal of Tourism and Hospitality. Kathmandu: International School of Tourism and Hotel Management, 4 (1):1-33.

Letizia, C. (2013) The goddess Kumārī at the Supreme Court Divine kinship and secularism in Nepal. Focaal-Journal of Global and Historical Anthropology 67: 32-46. 
Lidke, J. S. (2015) Royal Kumārī - The Goddess Who Peers Through The Eyes of a Child. Sutra Journal. (Retrieved from: http://www.sutrajournal.com/royalKumārī-the-goddess-who-peers-through-the-eyes-of-a-child).

- (2010) Kumārī: Nepal's Eternally Living Goddess. In Goddesses in World Culture (Volume 1: Asian and Africa). Patricia Monaghan (ed.). Oxford: Praeger Press, 85-98 (Retrieved from: https://www.academia.edu/13710400/Kumārī_ Nepal_s_Eternally_Living_Goddess).

MacCannell, D. (1973). Staged Authenticity: Arrangement of Social Space in Tourist Settings. The American Journal of Sociology, 79 (3): 589-603

Schocken Books.

(1976). The Tourist: A New Theory of Leisure Class. New-York:

Mccarthy, J. (2015) The Very Strange Life Of Nepal's Child Goddess. parallels MANY STORIES, ONE WORLD (Retrieved from: http://www.npr.org/sections/parallels /2015/05/28/410074105/the-very-strange-life-of-nepals-child-goddess).

Ranabhat, R. (2016) Living Goddess Kumārī Its Significance to Hindus in Nepal and Biblical Response. Torch Trinity Graduate University (A Paper Presented in Partial Fulfillment Of the Requirements for the Course). (Retrieved from: https://www.academia.edu/31836274/LIVING_GODDESS_KUMĀRI_ITS_ SIGNIFICANCE_TO_HINDUS_IN_NEPAL_and_BIBLICAL_RESPONSE).

Redfoot, D.L. (1984). Touristic Authenticity, Touristic Angst and Modern Reality. Qualitative Sociology, 7 (4): 291-309.

Shakya, D. (2010) Hamro Sanskritima Devi Tulaja Ra Kumārīko Sthan (English translation: Position of Tulaja and Kumārī Goddesses in our culture). Kathmandu: Kumārī Prakashan.

Theobald, W.F. (1998). Global Tourism 2nd Edition, Butterworth - Heinemann.

Tree, I. (2015) Meet Nepal's Living Goddesses. National Geographic (Retrieved from: http://www.myrepublica.com/news/5339/

Wang, N. (1999). Rethinking Authenticity in Tourism Experience. Annals of Tourism Research 26(2): 349-70.

Yun, C. (2011) Life after the living goddess Two former Kumārīs find their space in modern Kathmandu. Nepali Times. (Retrieved from: http://nepalitimes. com/news.php?id=18515\#.WONSZlKB2vs).

\section{Personal Interviews:}

Shakya, G. (2017). President of Indra Jatra Management Committee, Ministry of Culture, Tourism and Civil Aviation, Nepal 
Kunwar, R. R. (2017). Professor and former dean of faculty of Humanities in Tribhuvan University, Tourism expert/writer

Shrestha, D. (2017). Present, local club, Kathmandu which works to preserve the Kumārī culture 